\title{
PELATIHAN PENGEMBANGAN POTENSI DESA MELALUI SEKTOR UNGGULAN UBI SEBAGAI UPAYA PENINGKATAN EKONOMI MASYARAKAT DI DESA TOHKUNING KABUPATEN KARANGANYAR
}

\author{
Yofhi Septian Panglipurningrum ${ }^{1 *}$, Agus Utomo' ${ }^{2)}$, Lukman Akhmad Imron Pahlawi ${ }^{3)}$ \\ STIE Adi Unggul Bhirawa Surakarta \\ *Email: yofhi.septian@stie-aub.ac.id, agus_utomo@stie-aub.ac.id, lukman.pahlawi@gmail.com
}

\begin{abstract}
ABSTRAK
Kegiatan Pengabdian Kepada Masyarakat ini menggunakan prinsip pendampingan, pemberdayaan masyarakat, dimana pengabdi bertindak sebagai fasilitator. Pendampingan adalah suatu kegiatan konsultasi untuk nmemfasilitasi dan memotivasi dengan tujuan menyelesaikan suatu permasalahan yang dihadapi oleh kelompok masyarakat.Pemberdayaan adalah suatu upaya memulihkan atau meningkatkan keberdayaan suatu komunitas utuk mampu berbuat sesuai dengan harkat dan martabat mereka dalam melaksanakan hak-hak dan tanggungjawab mereka sebagai manusia dan warga negara. Kegiatan sosialisasi marketing umkm churros ubi di Desa Tohkuning yang dilaksanakan pada tanggal 15 Agustus 2019. Sosialisasi ini bertujuan untuk memberikan pengetahuan kepada masyarakat tentang bagaimana suatu produk dikemas secara baik dan benar, strategi pemasaran produk yang baik dan benar serta mengetahui sasaran yang akan dituju dari produk churros ubi tersebut. Dengan adanya kegiatan ini Masyarakat Desa Tohkuning mendapatkan pengetahuan tentang menginovasi produk dan pemasaran produk UMKM. Sehingga dapat menbantu perekonomian masyarakat di Desa Tohkuning.
\end{abstract}

Kata kunci: potensi desa, sektor unggulan, peningkatan ekonomi.

\section{PENDAHULUAN}

Desa Tohkuning merupakan salah satu dari 11 Desa di Kecamatan Karangpandan, Kabupaten Karanganyar Provinsi Jawa Tengah yang mempunyai luas wilayah 551,12 Ha dan memiliki 7 dusun. Jumlah penduduk tahun 2019 berkisar 5.503 jiwa dengan jumlah KK 1.605. Kondisi ekonomi di Desa Tohkuning terdiri dari berbagai bidang, yaitu pertanian, perkebunan, peternakan, industri kecil, perdagangan dan sektor jasa.

Beberapa masyarakat di Desa Tohkuning sudah memiliki UMKM dengan berbagai inovasi. Tetapi masyarakat masih memiliki kendala dalam memasarkan produknya. Masyarakat masih belum berani untuk memasarkan produknya di luar desa. Dalam pengembangan inovasi potensi lokal yang hendak diberdayakan adalah pengembangan produk usaha kecil bersama dengan masyarakat sekitar.

Jumlah penduduk Desa Tohkuning tahun 2019 berkisar 5489 jiwa dengan 1605 KK terdiri Laki-laki sebanyak 2676 jiwa, Perempuan 2813 jiwa. Desa Tohkuning, Kecamatan Karangpandan, Kabupaten Karanganyar, Provinsi Jawa Tengah mempunyai luas wilayah 551,12 Ha yang terbagi menjadi 7 dusun yaitu : Dusun Jetis, Dusun Musuk, Dusun Robyong, Dusun Dengkeng, Dusun Salam, Dusun Pendowo Rejo, Dusun Sendang Songo.

Produk yang dihasilkan adalah pengolahan Ubi yang diolah menjadi Churros Ubi dan Ubi Gulung. Pengembangan produk usaha tersebut dapat meningkatkan pendapatan perkapita masyarakat dengan memunculkan usaha-usaha kecil yang dapat membuka lapangan pekerjaan sehingga mengurangi angka pengangguran di Desa Tohkuning

Churros adalah jajanan asal Spanyol berupa makanan ringan yang sedang ngehits saat ini. Churros Ubi ini merupakan inovasi dari kelompok kami dengan tujuan untuk menambah nilai jual terhadap ubi itu sendiri. Tekstur dari churros ubi ini renyah diluar tetapi lembut dibagian dalam dan terdapat beberapa varian rasa seperti keju, coklat, vanilla latte, tiramisu dan matcha.

Selain Churros Ubi kami juga membuat satu produk lagi yaitu Ubi Gulung. Ubi Gulung merupakan inovasi makanan kekinian yang bebahan dasar ubi. Dinamakan Ubi gulung karena Ubi yang telah direbus digulung dengan kulit lumpia dan diberi gula setelah itu digoreng. Tekstur Ubi Gulung juga renyah, dan terdapat juga beberapa varian rasa yaitu, keju, coklat, vanilla latte, tiramisu dan matcha. 
Dengan ini kami mengharapkan produk ini mampu menembus pasar dan masyarakat dapat menerima produk tersebut. Selain inovasi produk tersebut kita juga membuat kemasan yang semenarik mungkin sehingga konsumen tertarik untuk membeli produk ini.

\section{METODE PELAKSANAAN}

\section{Khalayak Sasaran Strategis}

Jumlah penduduk tahun 2019 berkisar 5.503 jiwa dengan jumlah KK 1.605. Kondisi ekonomi di Desa Tohkuning terdiri dari berbagai bidang, yaitu pertanian, perkebunan, peternakan, industri kecil, perdagangan dan sektor jasa. Beberapa masyarakat di Desa Tohkuning sudah memiliki UMKM dengan berbagai inovasi. Tetapi masyarakat masih memiliki kendala dalam memasarkan produknya. Masyarakat masih belum berani untuk memasarkan produknya di luar desa. Dalam pengembangan inovasi potensi lokal yang hendak diberdayakan adalah pengembangan produk usaha kecil bersama dengan masyarakat sekitar.

\section{Metode Pelaksanaan}

Tahap 1 Observasi bersama masyarakat. Selanjutnya Tahap 2 Penyusunan Program Bersama Masyarakat sebagai berikut: a) Kontak awal dan penyepakatan tahapan proses kegiatan.b) Pengumpulan data dan informasi di lokasi KKN.Tahap 3 adalah sebagai berikut a) Indentifikasi masalah (analisis kondisi wilayah) b) Identifikasi potenssi c) Identifikasi program, d) Rumusan tujuan, e) Penyusunan Rencana Tindak Lanjut (RKTL) sebagai tahapan proses pelaksanaan kegiatan. Tahap 3 sebagai berikut: Sosialisasi Bersama Masyarakat,Tahap 4 Pelaksanaan Kegiatan Bersama Masyarakat Tahap 5 Pelaporan Kesepakatan program dan kegiatan antara mahasiswa dan masyarakat (waktu, dana, tahapan pelaksanaan) a)Pelaksanaan tahapan kegiatan (sesuai dengan RKTL) b) Monitoring dan evaluasi (kordes) Hard file berupa hasil kegitaan dalam bentuk makalah soft file dalam bentuk jurnal sebagai luaran

\section{Indikator Keberhasilan}

Indikator keberhasilan dari pelatihan ketrampilan dan pendampingan ini adalah :

1. Tanggapan dan respon para peserta yang sangat antusias.

2. Tingkat equivalent ( tingkat penyelesaian) dalam pelatihan ketrampilan dalam pembuatan Churos ubi ungu sebagai unggulan desa Tohkuning.

3. Daya kreativitas para peserta terpacu tidak hanya yang dilatihkan oleh Tim pelaksana seperti : pembuatan aneka makanan yang berasal dari ubi ungu.

4. Diharapkan dapat menambah penghasilan bagi warga desa tohkuning.

\section{HASIL DAN PEMBAHASAN \\ Hasil Kegiatan Pengabdian}

Hasil kegiatan pengabdian ini tidak sedikit selain memotivasi para peserta untuk berjiwa kewirausahaan namun juga peningkatan ketrampilan peserta dalam membuat kalung dan dasi batik serta produk yang lain berabahan perca batik. Jiwa kewirausahyaan ini akan memacu daya kreativitas para peserta yang pada akhirnya akan meningkatkan ekonomi /penghasilan keluarga.

Hasil kegiatan pengabdian ini bagi Tim Pelaksana berupa laporan kegiatan yang ditulis dalam format jurnal ilmiah serta diterbitkan pada media cetak (atau media online yang lain). Semua program kerja yang dibuat telah terlaksana sesuai dengan rencana. Partisipasi dan dukungan masyarakat cukup tinggi dimana masyarakat turut aktif dalam pelaksanaan program sehingga masyarakat dapat mengambil manfaatnya.

Dengan adanya kegiatan Pengabdian kepada Masyarakat Desa Tohkuning mendapatkan pengetahuan tentang menginovasi produk dan pemasaran produk UMKM. Sehingga diharapkan dapat membantu perekonomian masyarakat di Desa Tohkuning.

\section{Pembahasan}

Sosialisasi "Pengembangan Potensi Desa Melalui Pengembangan Sektor Unggulan Ubi (Pembuatan Churros Ubi dan Ubi Gulung) Dan Saluran Pemasaran Produk Sebagai Upaya 
Peningkatan Ekonomi Masyarakat”. Kegiatan sosialisasi ini dilakukan pada tanggal 15 Agustus 2019 pada pukul 14.00 sampai pukul 16.00 WIB. Kegiatan ini diikuti oleh para mahasiswa dan mengundang ibu-ibu PKK Desa Tohkuning. Acara ini berlagsung di Balai Desa Kelurahan Desa Tohkuning.

Sosialisasi ini juga bertujuan untuk memberikan pengetahuan kepada masyarakat tentang bagaimana suatu produk dikemas secara baik dan benar, strategi pemasaran produk yang baik dan benar serta mengetahui sasaran yang akan dituju dari produk churros ubi tersebut.

Evaluasi

Pelaksanaan Kegiatan Pengabdian kepada Masyarakat STIE AUB Surakarta di Desa Tohkuning, Kecamatan Karangpandan, Kabupaten Karanganyar, Provinsi Jawa Tengah berjalan dengan baik dan lancar. Semua program kerja yang dibuat telah terlaksana sesuai dengan rencana. Partisipasi dan dukungan masyarakat cukup tinggi dimana masyarakat turut aktif dalam pelaksanaan program sehingga masyarakat dapat mengambil manfaatnya.

Dengan adanya kegiatan Pengabdian kepada Masyarakat Desa Tohkuning mendapatkan pengetahuan tentang menginovasi produk dan pemasaran produk UMKM. Sehingga diharapkan dapat membantu perekonomian masyarakat di Desa Tohkuning.

\section{KESIMPULAN DAN SARAN}

\section{Kesimpulan}

Pelatihan ketrampilan dan pendampingan pembuatan kalung dan dasi batik ini sangat mendukung pelestarian budaya tradisional batik selain untuk mengurangi limbah indstri tektil, perca batik yang dibuat kalung dan dasi batik ini mempunyai nilai jual yang tinggi.

Pelatihan ketrampilan ini akan menumbuhkan jiwa kewirausahaan dan ide kreatif para peserta. Pelatihan ketrampilan ini sangat diinginkan oleh peserta, bahkan mereka ingin kunjungan rutin dan berkesinambungan untuk menambah pengetahuan dan ketrampilan yang lain.

\section{Saran}

Saran-saran yang bisa diberikan atas kendala yang dihadapi dalam pelaksanaan kegiatan adalah

1. Waktu pelatihan sebaiknya disesuaikan dengan waktu para peserta yang kebanyakn untuk ibu rumah tangga.

2. Peserta lebih banyak diberikan edukasi tentang tat kelola bahan agar tidak mengalami kerugiansaat menjalankan usaha.

\section{DAFTAR PUSTAKA}

Al Hidayah, Al Hidayah. 2011. Perencanaan Pengembangan Lahan Tanaman Ubi Jalar (Ipomoea Batatas) Kecamatan Matesih Kabupaten Kranganyar. Skripsi Thesis. Universitas Muhammadiyah Surakarta.

Klimchuk, Marianne dan Sandra A. Krasovec. 2006. Desain Kemasan. Jakarta: Erlangga.

Kotler dan Keller. 2009. Manajemen Pemasaran. Jilid I. Edisi ke 13. Jakarta: Erlangga.

Kotler, Philip. 1999. Manajemen Pemasaran. Jilid II. Edisi Milenium. Jakarta: Prenhallindo.

Rangkuti, Freddy. 2005. Analisis SWOT: Teknik Membedah Kasus Bisnis. Jakarta: Gramedia.

Simamora, Bilson. 2007. Panduan Riset dan Perilaku Konsumen. Jakarta: Gramedia.

Sutomo, Budi. 2007. Sukses Wirausaha Roti Favorit. Jakarta. Puspa Swara.

Wirakusumah, Emma S. 2005. Menikmati Telur. Jakarta. Gramedia. 